\title{
$\mathrm{CRF}_{1}$ receptor antagonists attenuate escalated cocaine self- administration in rats
}

\author{
Sheila E. Specio, \\ Committee on the Neurobiology of Addictive Disorders, SP30-2400, The Scripps Research Institute, \\ 10550 North Torrey Pines Road, La Jolla, CA 92037, USA
}

\section{Sunmee Wee,}

Committee on the Neurobiology of Addictive Disorders, SP30-2400, The Scripps Research Institute, 10550 North Torrey Pines Road, La Jolla, CA 92037, USA, e-mail: sunmee@scripps.edu

\section{Laura E. O’Dell,}

Department of Psychology, The University of Texas at El Paso, El Paso, TX 79968, USA

\author{
Benjamin Boutrel, \\ Center for Psychiatric Neuroscience, Department of Psychiatry, University of Lausanne, Site de \\ Cery, $\mathrm{CH}-1008$ Prilly, Switzerland
}

Eric P. Zorrilla, and

Committee on the Neurobiology of Addictive Disorders, SP30-2400, The Scripps Research Institute, 10550 North Torrey Pines Road, La Jolla, CA 92037, USA

\section{George F. Koob}

Committee on the Neurobiology of Addictive Disorders, SP30-2400, The Scripps Research Institute, 10550 North Torrey Pines Road, La Jolla, CA 92037, USA

\section{Abstract}

Rationale-Previous work suggests a role for stress-related corticotropin-releasing factor (CRF) systems in cocaine dependence. However, the involvement of activation of $\mathrm{CRF}_{1}$ receptors in rats self-administering cocaine with extended access is unknown.

Objective-The current study examined whether $\mathrm{CRF}_{1}$ receptor antagonist administration alters cocaine self-administration in animals given extended access.

Materials and methods-Wistar rats $(n=32)$ acquired cocaine self-administration $(0.66 \mathrm{mg} / \mathrm{kg}$ per infusion) in $1 \mathrm{~h}$ sessions for up to 11 days. Rats then were assigned to receive either daily short ( $1 \mathrm{~h}, \mathrm{ShA})$ or long (6 h, LgA) access to cocaine self-administration ( $n=7-9$ per group). Following escalation of intake, animals received one of two selective $\mathrm{CRF}_{1}$ antagonists: antalarmin (6.3-25 $\mathrm{mg} / \mathrm{kg}$, i.p.) or $N, N$-bis(2-methoxyethyl)-3-(4-methoxy-2-methylphenyl)-2,5-dimethyl-pyrazolo [1,5a]pyrimidin-7-amine (MPZP; 3.6-27.5 mg/kg, s.c.).

Results-By day 11 of the escalation period, $\operatorname{LgA}$ rats increased their cocaine intake, reaching an intake level of $15.1 \mathrm{mg} / \mathrm{kg}$, compared to $11.1 \mathrm{mg} / \mathrm{kg}$ in ShA rats, during the first hour of sessions. Antalarmin reduced cocaine self-administration at the highest dose selectively in the LgA group but not the ShA group. MPZP reduced cocaine intake both in LgA and ShA rats. However, MPZP did so at a lower dose in $\operatorname{LgA}$ rats than in ShA rats. Within the LgA group, MPZP decreased cocaine intake in the first 10 min (loading phase) as well as in the latter session intake (maintenance phase). 
Conclusion-The data suggest that hypersensitivity of the CRF system occurs with extended access to cocaine self-administration and that this altered CRF system may contribute to the increased motivation to self-administer cocaine that develops during psychostimulant dependence.

\section{Keywords}

Cocaine; Self-administration; Escalation; Rats; Corticotropin-releasing factor; Addiction; Antalarmin; MPZP

\section{Introduction}

Corticotropin-releasing factor (CRF) is a 41-amino-acid peptide identified as a hypothalamic releasing factor (Vale et al. 1981). CRF stimulates the release of adrenocorticotropic hormone (ACTH) from the pituitary into the bloodstream, which releases glucocorticoids from the adrenal gland. These hypothalamic-pituitary-adrenal (HPA) hormones play an important role in physiological responses to stress (for reviews, see De Souza 1995; Koob 1999a). In addition, the central nervous system contains CRF in several extrahypothalamic brain regions where it coordinates behavioral and autonomic responses to stressors (Cummings et al. 1983; Erb et al. 2001). Extracellular CRF levels and CRF synthesis increase in the amygdala in response to physical, physiological, and social/psychological stressors (Merlo-Pich et al. 1995; Makino et al. 1999; for reviews, see Zorrilla and Koob 2004; Bale and Vale 2004). To date, two genes encoding mammalian CRF receptors $\left(\mathrm{CRF}_{1}\right.$ and $\left.\mathrm{CRF}_{2}\right)$ have been identified (Hauger et al. 2006; Bale and Vale 2004; Chang et al. 1993; Lovenberg et al. 1995). While evidence indicates a role of $\mathrm{CRF}_{1}$ receptors in anxiety-like behaviors in laboratory animals (Zorrilla and Koob 2004; McElroy et al. 2002), $\mathrm{CRF}_{2}$ receptors appear to be related to appetite regulation and possibly modulation of anxiety-like behavior (for review, see Fekete and Zorrilla 2007).

The development of drug dependence has been hypothesized to involve allostatic dysregulation of brain reward function (Koob and Le Moal 1997, 2005). In addition to disruption of reward neurotransmission, the recruitment of brain stress systems, such as noradrenergic and CRF neurocircuitry, may contribute to the onset of drug dependence and addiction (Koob 2003). Dysphoria and anxiety are reported among the major drug-withdrawal symptoms in drugdependent humans (Kampman et al. 1998), and CRF and norepinephrine may possess a feedforward interaction in driving anxiety-like responses (Koob 1999b).

The hypothesis that CRF may be involved in withdrawal-induced anxiety-like responses is supported by research showing an association between cocaine withdrawal and increased extracellular CRF levels in the amygdala, as well as depleted amygdala CRF tissue content (Richter and Weiss 1999; Zorrilla et al. 2001). Intracranial administration of a peptide CRF receptor antagonist blocks cocaine withdrawal-induced anxiety-like behavior in rats (Basso et al. 1999). An interplay between cocaine and the brain stress systems is demonstrated by the facilitation of cocaine self-administration in rats that are high-responding to novelty (Piazza et al. 2000) and the blockade of acquisition and maintenance of cocaine self-administration following bilateral adrenalectomy (Goeders and Guerin 1996a). Additionally, a specific stressor, such as noncontingent footshock stress, increases corticosterone and is correlated with an increased acquisition rate of cocaine self-administration (Goeders and Guerin 1994, 1996b). Similarly, repeated corticosterone treatments promote the acquisition of cocaine selfadministration (Mantsch et al. 1998). There also is downregulation of CRF receptors in the medial prefrontal cortex, nucleus accumbens, olfactory tubercle, and amygdala following cocaine administration (Goeders et al. 1990). Pretreatment with the $\mathrm{CRF}_{1}$ antagonist $\mathrm{CP}-154,526$ results in dose-dependent decreases in cocaine self-administration in rats with limited daily drug access $(1 \mathrm{~h} /$ day) yet does not affect food-reinforced responding (Goeders and Guerin 2000). The CRF system involvement is not limited to the acquisition and 
maintenance of cocaine self-administration. It was shown that the CRF system stimulation induces reinstatement of cocaine-seeking behavior in rats during withdrawal (Erb et al. 2001, 2006). Taken together, these data suggest that activation of CRF systems in the brain may be involved in the development of the emotional dysregulation hypothesized to motivate drug intake in cocaine dependence.

In our laboratory, daily, extended access to cocaine has been shown to produce an increase in self-administration of the drug over sessions (termed "escalation"; Ahmed and Koob 1998;

Wee et al. 2007). The increased drug intake with extended access in rats provides some face validity for compulsive drug intake in humans (American Psychiatric Association 2000). Furthermore, the increased cocaine self-administration with extended access strongly correlates with an increasing threshold for intracranial self-stimulation (Ahmed et al. 2002), suggesting decreased brain reward function during the escalation of cocaine selfadministration. This finding, in turn, supports the construct validity of this model for the development of drug dependence (Koob et al. 1997; Koob and Le Moal 1997; Sinha et al. 2000).

Previous studies have shown that $\mathrm{CRF}_{1}$ antagonists have differential effects on ethanol selfadministration in dependent vs nondependent rats (Funk et al. 2007; Sabino et al. 2006; Heilig and Koob 2007). Therefore, the present study tested the hypothesis that $\mathrm{CRF}_{1}$ receptor blockade differentially affects rats with a history of short and extended access to cocaine. To test the hypothesis, we examined the effect of two non-peptide $\mathrm{CRF}_{1}$ receptor antagonists, antalarmin and $N, N$-bis(2-methoxyethyl)-3-(4-methoxy-2-methylphenyl)-2,5-dimethyl-pyrazolo[1,5a] pyrimidin-7-amine (MPZP), on cocaine self-administration under short-access (ShA, $1 \mathrm{~h} /$ day) and long-access ( $\mathrm{LgA}, 6 \mathrm{~h} /$ day) conditions. We report that $\mathrm{CRF}_{1}$ receptor antagonists more effectively decrease the increased cocaine intake of $\mathrm{LgA}$ rats than the intake of ShA rats.

\section{Materials and methods}

\section{Animals}

Thirty-two male Wistar rats (Charles River, Kingston, NY, USA), weighing 250-300 g at the start of the experiment, were group-housed (two to three per cage) on a reverse light/dark cycle (lights off 0800 to 2000 hours), in a climate-controlled vivarium. All behavioral testing occurred during the dark cycle. Food and water were freely available unless otherwise specified. All procedures met the guidelines of the National Institutes of Health Guide for the Care and Use of Laboratory Animals (The National Academies Press 1996).

\section{Drugs}

Cocaine hydrochloride (National Institute on Drug Abuse, Rockville, MD, USA) was dissolved in sterile physiological saline to $0.25 \mathrm{mg} / 0.1 \mathrm{ml}$ per infusion. $N$-butyl- $N$-ethyl-2,5,6trimethyl-7-(2,4,6-trimethylphenyl)-7H-pyrrolol[2,3-d]pyrimidin-4-amine hydrochloride (antalarmin hydrochloride, Sigma, St. Louis, MO, USA) was initially dissolved in $1 \mathrm{M} \mathrm{HCl}$ (a volume equal to $5 \%$ of the final volume), then suspended in a $0.5 \%(w / v)$ low-viscosity carboxymethyl-cellulose (Sigma) saline solution. This solution was back-titrated with $1 \mathrm{M}$ $\mathrm{NaOH}$ to a pH of $\sim 4$ and injected at a volume of $5 \mathrm{ml} / \mathrm{kg}$. MPZP was synthesized by Dr. Peter Wirsching (Department of Chemistry, The Scripps Research Institute). The methoxy substituents in the "top" MPZP alkyl unit confer increased hydrophilicity compared to the parent compound or antalarmin, yielding a $\mathrm{CRF}_{1}$ antagonist with lipophilicity more typical of central nervous system-acting drug-like molecules (Zorrilla and Koob 2004). MPZP was solubilized in $1 \mathrm{M} \mathrm{HCl}$, diluted in hydroxypropyl $\beta$-cyclodextrin ( $20 \% \mathrm{w} / \mathrm{v}$ final concentration, Cavitron 82004, Cargill, Wayzata, MN, USA) saline solution, back-titrated with $\mathrm{NaOH}$ to a 
final $\mathrm{pH}$ of 4.5 , and injected at a volume of $2 \mathrm{ml} / \mathrm{kg}$. Figure 1 presents the $\mathrm{CRF}_{1}$ antagonists under study.

Both MPZP and antalarmin have high affinity for rat $\mathrm{CRF}_{1}$ receptors (Table 1). Like antalarmin, MPZP is a selective $\mathrm{CRF}_{1}$ antagonist. MPZP has a 5-10 $\mathrm{nM}$ affinity for the $\mathrm{CRF}_{1}$ receptor and negligible activity at the $\mathrm{CRF}_{2}$ receptor. In vitro receptor autoradiography studies have shown that MPZP does not displace $\left[{ }^{125} \mathrm{I}\right]-\mathrm{Tyr}^{0}$-sauvagine binding from rat lateral septum or ventromedial hypothalamus $\left(\mathrm{CRF}_{2}\right.$-like binding $)$ at a concentration $(1 \mu \mathrm{M})$ that concurrently displaces the majority of $\left[{ }^{125} \mathrm{I}\right]-\mathrm{Tyr}^{0}$-sauvagine from the cerebral cortex $\left(\mathrm{CRF}_{1}\right.$ like binding). Although the binding affinity of MPZP for $\mathrm{CRF}_{1}$ receptors is slightly less potent than that of antalarmin, MPZP has lipophilicity 3.5 to 4 times lower than that of antalarmin and in a range more typical of central nervous system-acting therapeutics (compare cLog $P$ and $\operatorname{cLog} D$ in Table 1; Zorrilla and Koob 2004). The molecular volume and polar surface area of MPZP also are consistent with an absorbable, blood-brain barrier-penetrating molecule (Kelder et al. 1999;Zhao et al. 2007;Fu et al. 2005; Liu et al. 2004).

\section{Apparatus}

Behavioral training occurred in operant-conditioning chambers (Coulbourn Instruments, Allentown, PA, USA) housed in sound-attenuating cubicles. All chambers were equipped with two retractable levers, a dispenser for food pellets (P.J. Noyes, Lancaster, NH, USA), and a syringe pump (Model A, Razel Scientific Instruments, Stamford, CT, USA) delivering $0.1 \mathrm{ml}$ of cocaine solution over $4 \mathrm{~s}$ via Tygon tubing attached to liquid swivels (Model 375, Instech Labs, Plymouth Meeting, VA, USA). A time-out (20 s) followed each infusion, during which a cue light above the active lever was illuminated. At the start of a session, two levers were presented. Responding on the active lever resulted in reinforcement, whereas responding on the inactive lever resulted in no consequences but was recorded. Sessions were controlled and recorded by a personal computer with a custom interface and software.

\section{Intravenous surgery}

Rats were implanted with an indwelling catheter into the right jugular vein under 1-3\% isoflurane as described by Caine et al. (1993). Catheters were flushed daily with $0.2 \mathrm{ml}$ of sterile antibiotic solution containing Timentin $(100 \mathrm{mg} / \mathrm{ml}$; SmithKline Beecham Pharmaceuticals, Philadelphia, PA, USA) and heparin (30 USP units/ml). Catheter patency was checked by briefly aspirating blood from the catheter.

\section{Self-administration procedure}

Initially, rats were food-restricted ( $15 \mathrm{~g}$ per rat per day) and trained to press a lever for a food pellet (45 mg Formula A/I, Research Diets, New Brunswick, NJ, USA) under a fixed-ratio (FR) 1 schedule in 30-min sessions, twice daily for a total of 5 days before intravenous catheterization. During this period, the length of time-out following reinforcement was gradually increased $(1,5,10$, and $20 \mathrm{~s})$. After the animal reached the 20 -s time-out, food was available ad libitum for the remainder of the study. The rats then were implanted with intravenous catheters as described above.

After recovery from surgery, rats self-administered $0.25 \mathrm{mg}$ per infusion $(0.66 \mathrm{mg} / \mathrm{kg}$ per infusion) of cocaine in daily 1-h sessions under an FR1 schedule for a maximum of 11 days. Following these baseline sessions, animals were separated into two groups balanced for body weight and cocaine intake. The session length was kept to $1 \mathrm{~h}$ for one group (short access, ShA, $n=16$ ) and was increased to $6 \mathrm{~h}$ for the other group (long access, $\mathrm{LgA}, n=16$; escalation period). Sessions in this escalation period lasted for 11 to 15 days before testing with $\mathrm{CRF}_{1}$ receptor antagonists. Following the escalation period, the effects of antalarmin or MPZP on cocaine self-administration were tested in separate groups of ShA and LgA rats under an FR1 schedule. 
The antalarmin $(6.3-25 \mathrm{mg} / \mathrm{kg})$ pretreated animals were injected intraperitoneally $80 \mathrm{~min}$ before a test session. The MPZP (3.6-27.5 mg/kg) pretreated animals were injected subcutaneously $45 \mathrm{~min}$ before a test session. These doses and pretreatment time intervals were chosen based on previous studies with the anti-stress time course and potencies of these compounds (Zorrilla et al. 2002; Fekete et al. 2003). Doses of each drug were tested in a Latin square design. Test sessions were $1 \mathrm{~h}$ long and separated by one to two treatment-free daily escalation sessions.

\section{Data analyses}

Data were expressed as the first hour and total session cocaine intake (milligram per kilogram). To analyze changes in cocaine intake during the escalation period, a repeated-measures twoway analysis of variance (ANOVA) was used (access $\times$ session). Post-hoc comparisons were performed using the Student Neuman Keuls test. The effects of the $\mathrm{CRF}_{1}$ receptor antagonists on cocaine intake were evaluated using a repeated-measures two-way ANOVA (dose $\times$ access). In addition to a two-way ANOVA, we performed a dose-by-access linear trend contrast analysis. We subsequently identified the source of the interaction with dose using simple main effects (within subject) and individual means comparisons with Dunnett's test. Regarding the error bars in the figures, they reflect between-subject variability, whereas the statistical test used every animal as its own control. With dose-response functions, a powerful way of using analysis of variance is to do linear trend analysis (Bewick et al. 2004; Bretz et al. 2004; Rosner 1995; Sheskin 2004). With a significant dose-by-access linear trend contrast, a simple main effect of dose on cocaine intake within each group was performed using the error term, $\mathrm{MS}_{\mathrm{B} \times \text { subjw.groups }}\left[F=\mathrm{MS}_{b}\right.$ at $a 1 \mathrm{MS}_{\mathrm{B} \times \text { subjw.groups }}, b=$ dose, $a=$ access, Winer 1962) with a Dunnett's post-hoc test for individual mean comparisons.

Previous research in our laboratory demonstrated that rats self-administer more drug during the first 10 min (loading phase) than in any other 10-min period of a 1-h session (Kitamura et al. 2007; Wee et al. 2007). Therefore, we further analyzed the effect of MPZP and antalarmin on the pattern of cocaine intake within a test session only in $\mathrm{LgA}$ rats. Data in each test session were divided into the loading phase intake (first $10 \mathrm{~min}$ ) and the maintenance-phase intake (the average for the 10-min bin from 10-60 min) and subjected to a two-way ANOVA and a twoway linear contrast (dose $\times$ phase). The statistical packages used were Statview (SAS Institute, Cary, NC, USA), Statistical Package for the Social Sciences (Chicago, IL, USA), Instat, and Prism (GrapPad, San Diego, CA, USA).

\section{Results}

Figure 2a and $\mathrm{b}$ illustrate cocaine intake (milligram per kilogram) for ShA and LgA groups during the entire session and first hour, respectively. Data analyses of cocaine intake for the ShA group and the first hour of the LgA group during the first 11 days of escalation revealed a main effect of daily sessions $\left(F_{10,300}=9.031, p<0.0001\right)$, main effect of access $\left(F_{1,30}=7.347\right.$, $p<0.05)$, and an overall interaction $\left(F_{10,300}=2.996, p<0.01\right)$. Compared to escalation session 1 , the ShA group exhibited increased responding in sessions 10-11, whereas the LgA group exhibited increased $1 \mathrm{~h}$ responding earlier, beginning in session 3. LgA animals also significantly increased total session responding by session 3 . Cocaine intake within the first hour by LgA rats significantly exceeded that of ShA rats on day $5(p<0.01)$, continuing through sessions 6 to $11(p<0.001)$. Separation of the cocaine intake data into the respective antagonist treatment groups yielded the following results: The Antalarmin groups (ShA vs LgA) exhibited a main effect for daily sessions $\left(F_{10,150}=6.091, p<0.0001\right)$, an overall interaction

$\left(F_{10,150}=2.632, p<0.01\right)$, but no main effect for group on cocaine intake. The antalarmin LgA group increased intake by day 2 for the first hour and by day 4 for total session intake. The MPZP groups (ShA vs LgA) exhibited a main effect of daily sessions $\left(F_{13,130}=4.465\right.$, 
$p<0.0001)$, a main effect for group $\left(F_{1,130}=5.758, p<0.05\right)$, and an overall interaction

$\left(F_{13,130}=2.343, p<0.05\right)$ on cocaine intake. The MPZP LgA group increased intake by day 10 for the first hour and by day 3 for the total session intake. The separation of cocaine intake data into the respective antagonist treatment groups resulted in a lack of increased intake for either ShA group.

The two $\mathrm{CRF}_{1}$ antagonists differentially decreased cocaine intake (milligram per kilogram) during the test sessions. Two-way ANOVA of cocaine intake following antalarmin pretreatment (Fig. 3) revealed a main effect of access (ShA $n=8, \operatorname{LgA} n=9 ; F_{1,45}=5.446$, $p<0.05)$ but no main effect for antalarmin dose and no interaction. However, a dose-by-access linear trend contrast analysis showed a significant dose-by-access linear contrast $\left(F_{1,15}=5.05\right.$, $p<0.05$ ), indicating that the strength of the log-linear relation of antalarmin dose to cocaine intake differed significantly between access conditions. Please note that the denominator degrees of freedom $(d f)$ for an orthogonal contrast test is calculated as $N-J$, where $N$ is the sample size, and $J$ is the number of contrast coefficients (e.g., one coefficient for the overall linear dose trend and one coefficient for the linear dose $\times$ access interaction). Additionally, there was a simple main effect of dose of antalarmin on cocaine intake in $\mathrm{LgA}$ rats $\left(\mathrm{MS}_{b \text { at } a 1}=6.7(d f=3), \mathrm{MS}_{\mathrm{B} \times \text { subjw.groups }}=1.97(d f=45), F_{3,45}=3.41, p<0.05\right)$ with a significant decrease in cocaine intake at $25 \mathrm{mg} / \mathrm{kg}$ compared with the vehicle. In contrast, no simple main effect of dose on cocaine intake was found in ShA rats $\left(\mathrm{MS}_{b \text { at } a 1}=0.52, \mathrm{MS}_{\mathrm{B} \times \text { subjw.groups }}=1.97\right.$, $F_{3,45}=0.26, p>0.05$, Fig. 3).

MPZP decreased cocaine intake in both ShA and LgA rats (Fig. 4). Two-way ANOVA revealed an overall main effect for access ( $\operatorname{ShA} n=8, \operatorname{LgA} n=7 ; F_{1,39}=7.249, p<0.05$ ), a main effect for MPZP dose $\left(F_{3,39}=10.076, p<0.001\right)$ but no interaction. However, a two-way linear contrast showed a significant dose $\times$ access linear contrast interaction $\left(F_{1,13}=5.48, p<0.05\right)$.

Additionally, there was a simple main effect of dose on cocaine intake in both $\operatorname{LgA}$ and ShA rats [ $\mathrm{LgA}, \mathrm{MS}_{b}$ at $a 1=17.56(d f=3), \mathrm{MS}_{\mathrm{B} \times \text { subjw.groups }}=1.89(d f=39), F_{3,39}=9.29, p<0.01$; $\mathrm{ShA}$, $\mathrm{MS}_{b}$ at $\left.a 1=7.72(d f=3), \mathrm{MS}_{\mathrm{B} \times \text { subjw.groups }}=1.89(d f=39), F_{3,39}=4.01, p<0.05\right]$. Post hoc

Dunnett's tests showed a significant decrease in cocaine intake at $10 \mathrm{mg} / \mathrm{kg}(p<0.05)$ and 27.5 $\mathrm{mg} / \mathrm{kg}(p<0.01)$ in $\mathrm{LgA}$ rats and at $27.5 \mathrm{mg} / \mathrm{kg}$ in ShA rats $(p<0.05)$.

Cocaine intake during the loading phase was higher than that of the maintenance phase (Antalamin group, $5.2 \pm 0.6$ vs $2.0 \pm 0.1$; MPZP group, $5.9 \pm 0.5$ vs $2.6 \pm 0.2 \mathrm{mg} / 10 \mathrm{~min}$ after the vehicle pretreatment). When the effect of $\mathrm{CRF}_{1}$ antagonists on cocaine intake was compared between the loading and maintenance phases in $\operatorname{LgA}$ rats, neither a two-way ANOVA nor a two-way linear contrast found a significant interaction between dose and phase for antalarmin or for MPZP (data not shown). However, a two-way ANOVA showed a significant main effect of phase for antalarmin $\left(F_{1,48}=52.0, p<0.001\right)$ and significant main effects of phase and dose for MPZP (phase, $F_{1,36}=46.6, p<0.001$; dose, $F_{3,36}=13.4, p<0.001$ ).

\section{Discussion}

Anxiety and dysphoria occur during cocaine abstinence in human cocaine users (Kampman et al. 1998). This negative emotional state is hypothesized to motivate the maintenance and persistence of drug intake via negative reinforcement mechanisms, thereby playing a critical role in the development of drug dependence (Koob and Le Moal 1997). Evidence supports the notion that the CRF system mediates anxiety and other dysphoric states (for review, see Zorrilla and Koob 2004; Bale and Vale 2004), and recruitment of the CRF system has been hypothesized to be involved in drug dependence in humans (Koob 1999a). The present study tested whether rats with a history of extended access to cocaine and resultant escalation of intake showed increased sensitivity to the ability of $\mathrm{CRF}_{1}$ antagonists to reduce cocaine selfadministration, as would be predicted with increased activity of the CRF receptor system. 
Consistent with previous reports, $\operatorname{LgA}$ rats increased cocaine intake during the first hour and across 6-h sessions (Ahmed and Koob 1998; Wee et al. 2007). In humans, drug intake increases with the development of drug dependence (American Psychiatric Association 2000), supporting the face validity of the extended-access cocaine self-administration procedure as a model of cocaine dependence in humans. Under the present conditions, when all ShA rats were combined, increased cocaine intake was observed across daily sessions but to a much smaller degree and more slowly than the increase seen in first-hour intake in $\mathrm{LgA}$ rats. The hypothesis of differential activity of CRF systems in rats with a history of cocaine escalation was supported by the current findings. Systemic pretreatment with the $\mathrm{CRF}_{1}$ antagonist antalarmin decreased cocaine intake selectively in LgA rats at the $25 \mathrm{mg} / \mathrm{kg}$ dose. A previous study found that 30 min pretreatment of antalarmin did not alter the dose-response function of cocaine selfadministration in rhesus monkeys with limited ( $2 \mathrm{~h}$ ) daily drug access (Mello et al. 2006), which is consistent with the present finding that antalarmin had no effect in ShA rats. Similar to the present results, antalarmin ( $20 \mathrm{mg} / \mathrm{kg}$, i.p.) dose-dependently reduced escalated ethanol intake in ethanol-dependent rats tested during acute withdrawal yet did not influence ethanol self-administration in nondependent rats (Funk et al. 2007). Doses of antalarmin, similar to those used in the present study ( $20 \mathrm{mg} / \mathrm{kg}$, i.p.), were shown previously to inhibit spontaneous defensive withdrawal behavior as well as intracerebroventricular CRF-induced anxiogeniclike behavior in the elevated plus maze (Zorrilla et al. 2002). These data support the hypothesis that the CRF system contributes to the escalated drug intake of rats with extended drug access, a model of the development of drug dependence.

The $\mathrm{CRF}_{1}$ antagonist MPZP decreased cocaine intake in both ShA and LgA rats. However, MPZP reduced cocaine self-administration in LgA rats at a lower dose than in ShA rats, suggesting that cocaine intake by $\mathrm{LgA}$ rats was more sensitive to the blockade of $\mathrm{CRF}_{1}$ receptors than the intake by ShA rats. Doses of MPZP similar to those used in the present study reduced anxiety-like behavior in the defensive burying test (Fekete et al. 2003). Moreover, an increased time spent for defensive burying was found in LgA rats compared with ShA rats after 22 days of cocaine self-administration with extended access, which lasted over a month (Aujla et al. 2007). Thus, the data suggest that the physiological systems affected by cocaine selfadministration with extended access may reflect a hypersensitive state in the CRF system, which produces an increased anxiety-like state upon the exposure to shock stimulus in the defensive burying test and perhaps contributes to an increased cocaine intake.

The decreased cocaine intake in ShA rats by MPZP pretreatment was somewhat unexpected because previous reports using various doses and regimens of antalarmin, etomide, ketoconazole, astressin, and dexamethasone in rhesus monkeys and CP-154,526 in Wistar rats did not find a relationship between the CRF system and the acute reinforcing effects of cocaine (Mello et al. 2006; Broadbear et al. 1999; Przegalinski et al. 2005). However, consistent with the present results, $\mathrm{CP}-154,526$, a non-peptide $\mathrm{CRF}_{1}$ receptor antagonist, reduced cocaine selfadministration $(0.5 \mathrm{mg} / \mathrm{kg}$ per injection) and cocaine-induced conditioned place preference in rats (Goeders and Guerin 2000; Lu et al. 2003). Reasons for these differences are not clear, although possible explanations might include the doses used and the session paradigms. Thus, a relationship between the CRF system and the acute reinforcing effect of cocaine remains unresolved, but the increased cocaine intake associated with extended access appears particularly sensitive to the $\mathrm{CRF}_{1}$ antagonist effect.

The difference between the effects of antalarmin and MPZP on cocaine intake by ShA rats might be explained by pharmacokinetic variables related to the compounds' different lipophilicities or the different routes and vehicles of administration. Antalarmin, a pyrrolopyrimidine, is approximately 4.5 orders (30,000-fold) more hydrophobic than MPZP ( $\operatorname{LLog} P=6.98$ vs 2.52 , respectively). The very high lipophilicity of antalarmin results in poor aqueous solubility and low bioavailability of the compounds, with a pharmacokinetic profile 
unfavorable for accumulation of high central levels (Zorrilla and Koob 2004). The use of hydroxypropyl $\beta$-cyclodextrin as a vehicle excipient also may have increased central availability of MPZP by increasing solubility and distribution and, perhaps, reducing degradation (Strickley 2004).

In the present study, increased cocaine intake in $\operatorname{LgA}$ rats appears to be related to the increased sensitivity of the CRF system with extended access to cocaine. Thus, one may speculate that the loading phase is more sensitive than the maintenance phase of the 1-h test session, as presumably, the loading phase would reflect an attempt to reverse the hypothesized increase in CRF activity observed during cocaine withdrawal (Richter and Weiss 1999). However, further analysis of the effect of the $\mathrm{CRF}_{1}$ antagonists on cocaine intake by LgA rats during the loading and the maintenance phases showed no significant interaction between the antagonist dose and phase intake in $\operatorname{LgA}$ rats. This suggests that, although the cocaine intake during the loading phase was higher than that of the maintenance phase, antalarmin and MPZP did not differentially decrease the loading- and maintenance-phase cocaine intake. On the other hand, MPZP had effects throughout the session (six 10-min bins) whereas antalarmin did not. This may reflect a longer duration of action of MPZP than antalarmin. The first half-life of antalarmin-related compound CP-154,526 was $0.9 \mathrm{~h}$ in rats (Keller et al. 2002), and the halflife of MPZP-related compound DMP904 was $46 \mathrm{~h}$ in dogs (Gilligan et al. 2000).

Neuroadaptation in the CRF system in the extended amygdala has been proposed to drive the negative motivational state associated with abstinence in drug-dependent humans (Koob 2003). Research substantiating this hypothesis includes findings that extracellular CRF levels are increased in the central amygdala during cocaine, ethanol, cannabinoid, and opioid withdrawal in rats (Richter and Weiss 1999; Merlo-Pich et al. 1995; Rodriguez de Fonseca et al. 1997; Weiss et al. 2001, respectively) and that tissue content levels of CRF in the amygdala are depleted during withdrawal from cocaine or ethanol (Zorrilla et al. 2001; Funk et al. 2006). CRF antagonists have been found to reduce negative emotional states during withdrawal from cocaine (Basso et al. 1999, Przegalinski et al. 2005), methamphetamine (Moffet and Goeders 2007), nicotine (Bruijnzeel et al. 2007), and ethanol (Baldwin et al. 1991, Rassnick et al. 1993; Menzaghi et al. 1994). Such negative emotional states may indicate decreased brain reward function, which has been observed in a previous study in LgA rats (Ahmed et al. 2002). Altogether, these results support a hypothesis that CRF system activity increases, likely in the extended amygdala, with extended access to cocaine self-administration, which in turn may contribute to an increase in cocaine intake in $\operatorname{LgA}$ rats.

Rather than an effect on extrahypothalamic CRF systems, a possible alternative explanation for the current findings is that antalarmin and MPZP reduced cocaine intake because of an ability of $\mathrm{CRF}_{1}$ antagonists to reduce HPA activation. For example, the structurally related compound DMP904 inhibited ACTH release from rat pituitary corticotropes (Li et al. 2005) and dose-dependently inhibited the stress-induced increase in plasma corticosterone in rats (Lelas et al. 2004). Similarly, antalarmin (20 mg/kg, i.p.) blocked CRF-induced increases in plasma ACTH levels (Webster et al. 1996). The understanding of the relationship between the acute reinforcing effect of cocaine and the HPA axis is evolving (Marinelli et al. 1997). Mantsch et al. (1998) reported that dexamethasone, a glucocorticoid receptor agonist, inhibited the acquisition of cocaine self-administration in rats, yet corticosterone treatment promoted acquisition. Later studies found no clear relationship between glucocorticoids and stressinduced escalation of cocaine intake, cocaine-seeking behavior, or the discriminative stimulus properties of cocaine in rats (Mantsch and Katz 2006; Mantsch and Goeders 1999). Similarly, Broadbear et al. (1999) reported that cocaine-maintained responding was not altered by effective inhibitors of HPA axis hormonal responses in rhesus monkeys. Furthermore, under conditions similar to those in the present study, Mantsch et al. (2003) noted the development of tolerance in HPA axis responses to cocaine intake in LgA rats but not in ShA rats. Thus, 
cocaine exposure may initially activate the HPA axis (Marinelli and Piazza 2002), whereas prolonged cocaine exposure may result in a subsequent blunting of the HPA axis, with a compensatory sensitization of extrahypothalamic CRF systems (Lee et al. 1994; Pecina et al. 2006; Shepard et al. 2006).

In conclusion, the present study demonstrates that $\mathrm{CRF}_{1}$ receptor antagonists decreased cocaine intake in rats, especially in those with a history of extended, as opposed to brief, daily cocaine access. The data suggest that neuroadaptations in the CRF system may contribute to the increased motivation to self-administer cocaine that develops during psychostimulant dependence.

\section{Acknowledgments}

We gratefully acknowledge the technical assistance of Yanabel Grant and Robert Lintz and the chemical expertise of Kim Janda and Pete Wirsching for MPZP synthesizing. Additionally, we thank Mike Arends for editorial assistance. This is publication number 18741 from The Scripps Research Institute. The experimental protocol was in compliance with the National Institutes of Health Guide for Care and Use of Laboratory Animals (The National Academies Press, 1996). Additionally, there is no relationship with the organization supporting this research and no conflict of interest.

This study was supported by a National Institute on Drug Abuse Grant DA004398 (G.F.K).

\section{References}

Ahmed SH, Kenny PJ, Koob GF, Markou A. Neurobiological evidence for hedonic allostasis associated with escalating cocaine use. Nat Neurosci 2002;5:625-626. [PubMed: 12055635]

Ahmed SH, Koob GF. Transition from moderate to excessive drug intake: change in hedonic set point. Science 1998;282:298-300. [PubMed: 9765157]

American Psychiatric Association. Diagnostic and statistical manual of mental disorders. Vol. 4. American Psychiatric Press; Washington DC: 2000.

Aujla H, Martin-Fardon R, Weiss F. Rats with extended access to cocaine exhibit increased stress reactivity and sensitivity to the anxiolytic-like effects of the mGluR 2/3 agonist LY379268 during abstinence. Neuropsychopharmacology. 2007in press

Baldwin HA, Rassnick S, Rivier J, Koob GF, Britton KT. CRF antagonist reverses the "anxiogenic" response to ethanol withdrawal in the rat. Psychopharmacology 1991;103:227-232. [PubMed: 2027923]

Bale TL, Vale WW. CRF and CRF receptors: role in stress responsivity and other behaviors. Annu Rev Pharmacol Toxicol 2004;44:525-557. [PubMed: 14744257]

Basso AM, Spina M, Rivier J, Vale W, Koob GF. Corticotropin-releasing factor antagonist attenuates the "anxiogenic-like" effect in the defensive burying paradigm but not in the elevated plus-maze following chronic cocaine in rats. Psychopharmacology 1999;145:21-30. [PubMed: 10445369]

Bewick V, Cheek L, Ball J. Statistics review 9: One-way analysis of variance. Crit Care 2004;8:130136. [PubMed: 15025774]

Bretz F, Pinheiro JC, Branson M. On a hybrid method in dose finding studies. Methods Inf Med 2004;43:457-460. [PubMed: 15702200]

Broadbear JH, Winger G, Woods JH. Cocaine-reinforced responding in rhesus monkeys: pharmacological attenuation of the hypothalamic-pituitary-adrenal axis response. J Pharmacol Exp Ther 1999;290:1347-1355. [PubMed: 10454513]

Bruijnzeel AW, Zislis G, Wilson C, Gold MS. Antagonism of CRF receptors prevents the deficit in brain reward function associated with precipitated nicotine withdrawal in rats. Neuropsychopharmacology 2007;32:955-963. [PubMed: 16943772]

Caine, SB.; Lintz, R.; Koob, GF. Intravenous drug-self-administration techniques in animals. In: Sahgal, A., editor. Behavioural Neuroscience: a practical approach. Vol. 2. Oxford University Press; New York: 1993. p. 117-143. 
Chang CP, Pearse RV, O'Connell S, Rosenfeld MG. Identification of a seven transmembrane helix receptor for corticotropin-releasing factor and sauvagine in mammalian brain. Neuron 1993;11:1187-1195. [PubMed: 8274282]

Cummings S, Elde R, Ells J, Lindall A. Corticotropin-releasing factor immunoreactivity is widely distributed within the central nervous system of the rat: an immunohistochemical study. J Neurosci 1983;3:1355-1368. [PubMed: 6345725]

De Souza EB. Corticotropin-releasing factor receptors: physiology, pharmacology, biochemistry and role in central nervous system and immune disorders. Psychoneuroendocrinology 1995;20:789-819. [PubMed: 8834089]

Erb S, Petrovic A, Yi D, Kayyali H. Central injections of CRF reinstate cocaine seeking in rats after postinjection delays of up to $3 \mathrm{~h}$ : an influence of time and environmental context. Psychopharmacology 2006;187:112-120. [PubMed: 16767421]

Erb S, Salmaso N, Rodaros D, Stewart J. A role for the CRF-containing pathway from central nucleus of the amygdala to bed nucleus of the stria terminalis in the stress-induced reinstatement of cocaine seeking in rats. Psychopharmacology 2001;158:360-365. [PubMed: 11797056]

Fekete EM, Zorrilla EP. Physiology, pharmacology, and therapeutic relevance of urocortins in mammals: Ancient CRF paralogs. Front Neuroendocrinol 2007;28:1-27. [PubMed: 17083971]

Fekete, EM.; Zorrilla, EP.; Mason, BJ.; Wirsching, P.; Janda, KD.; Koob, GF. Program No. 538.13. Abstract Viewer and Itinerary Planner. Washington, D.C.: Society for Neuroscience; 2003. Anxiolytic-like effects of type 1 corticotropin-releasing factor receptor antagonists in the rat defensive burying test.

Fu XC, Song ZF, Fu CY, Liang WQ. A simple predictive model for blood-brain barrier penetration. Pharmazie 2005;60:354-358. [PubMed: 15918585]

Funk CK, O'Dell LE, Crawford EF, Koob GF. Corticotropin-releasing factor within the central nucleus of the amygdala mediates enhanced ethanol self-administration in withdrawn, ethanol-dependent rats. J Neurosci 2006;26:11324-11332. [PubMed: 17079660]

Funk CK, Zorrilla EP, Lee MJ, Rice KC, Koob GF. Corticotropin-releasing factor 1 antagonists selectively reduce ethanol self-administration in ethanol-dependent rats. Biol Psychiatry 2007;61:7886. [PubMed: 16876134]

Gilligan PJ, Baldauf C, Cocuzza A, Chidester D, Zaczek R, Fitzgerald LW, McElroy J, Smith MA, Shen HS, Saye JA, Christ D, Trainor G, Robertson DW, Hartig P. The discovery of 4-(3-pentylamino)-2,7dimethyl-8-(2-methyl-4-methoxyphenyl)-pyrazolo-[1,5-a]-pyrimidine: a corticotropin-releasing factor $\left(\mathrm{hCRF}_{1}\right)$ antagonist. Bioorg Med Chem 2000;8:181-189. [PubMed: 10968277]

Goeders NE, Bienvenu OJ, De Souza EB. Chronic cocaine administration alters corticotropin-releasing factor receptors in the rat brain. Brain Res 1990;531:322-328. [PubMed: 1963104]

Goeders NE, Guerin GF. Non-contingent electric footshock facilitates the acquisition of intravenous cocaine self-administration in rats. Psychopharmacology 1994;114:63-70. [PubMed: 7846208]

Goeders NE, Guerin GF. Effects of surgical and pharmacological adrenalectomy on the initiation and maintenance of intravenous cocaine self-administration in rats. Brain Res 1996a;722:145-152. [PubMed: 8813360]

Goeders NE, Guerin GF. Role of corticosterone in intravenous cocaine self-administration in rats. Neuroendocrinology 1996b;64:337-348. [PubMed: 8930934]

Goeders NE, Guerin GF. Effects of the CRH receptor antagonist CP-154,526 on intravenous cocaine self-administration in rats. Neuropsychopharmacology 2000;23:577-586. [PubMed: 11027923]

Hauger RL, Risbrough V, Brauns O, Dautzenberg FM. Corticotropin releasing factor (CRF) receptor signaling in the central nervous system: new molecular targets. CNS Neurol Disord Drug Targets 2006;5:453-479. [PubMed: 16918397]

Heilig M, Koob GF. A key role for corticotropin-releasing factor in alcohol dependence. Trends Neurosci 2007;30:399-406. [PubMed: 17629579]

Kampman KM, Volpicelli JR, McGinnis DE, Alterman AI, Weinrieb RM, D’Angelo L, et al. Reliability and validity of the Cocaine Selective Severity Assessment. Addict Behav 1998;23:449-461. [PubMed: 9698974] 
Kelder J, Grootenhuis PD, Bayada DM, Delbressine LP, Ploemen JP. Polar molecular surface as a dominating determinant for oral absorption and brain penetration of drugs. Pharm Res 1999;16:15141519. [PubMed: 10554091]

Keller C, Bruelisauer A, Lemaire M, Enz A. Brain pharmacokinetics of a nonpeptidic corticotropinreleasing factor receptor antagonist. Drug Metab Dispos 2002;30:173-176. [PubMed: 11792687]

Kitamura O, Wee S, Specio SE, Koob GF, Pulvirenti L. Escalation of methamphetamine selfadministration in rats: a dose-effect function. Psychopharmacology 2007;186:48-53. [PubMed: 16552556]

Koob GF. Stress, corticotropin-releasing factor, and drug addiction. Ann N Y Acad Sci 1999a;897:2745. [PubMed: 10676433]

Koob GF. Corticotropin-releasing factor, norepinephrine, and stress. Biol Psychiatry 1999b;46:11671180. [PubMed: 10560023]

Koob GF. Neuroadaptive mechanisms of addiction: studies on the extended amygdala. Eur Neuropsychopharmacol 2003;13:442-452. [PubMed: 14636960]

Koob GF, Caine SB, Parsons L, Markou A, Weiss F. Opponent process model and psychostimulant addiction. Pharmacol Biochem Behav 1997;57:513-521. [PubMed: 9218276]

Koob GF, Le Moal M. Drug abuse: hedonic homeostatic dysregulation. Science 1997;278:52-58. [PubMed: 9311926]

Koob GF, Le Moal M. Plasticity of reward neurocircuitry and the 'dark side' of drug addiction. Nat Neurosci 2005;8:1442-1444. [PubMed: 16251985]

Lee Y, Schulkin J, Davis M. Effect of corticosterone on the enhancement of the acoustic startle reflex by corticotropin releasing factor (CRF). Brain Res 1994;666(1):93-98. [PubMed: 7889373]

Lelas S, Wong H, Li YW, Heman KL, Ward KA, Zeller KL, et al. Anxiolytic-like effects of the corticotropin-releasing factor1 $\left(\mathrm{CRF}_{1}\right)$ antagonist DMP904 [4-(3-pentylamino)-2,7-dimethyl-8-(2methyl-4-methoxyphenyl)-pyrazolo-[1,5-a]-pyrimidine] administered acutely or chronically at doses occupying central $\mathrm{CRF}_{1}$ receptors in rats. J Pharmacol Exp Ther 2004;309:293-302. [PubMed: 14742750]

Li YW, Fitzgerald L, Wong H, Lelas S, Zhang G, Lindner MD, et al. The pharmacology of DMP696 and DMP904, non-peptidergic $\mathrm{CRF}_{1}$ receptor antagonists. CNS Drug Rev 2005;11:21-52. [PubMed: 15867951]

Liu X, Tu M, Kelly RS, Chen C, Smith BJ. Development of a computational approach to predict bloodbrain barrier permeability. Drug Metab Dispos 2004;32:132-139. [PubMed: 14709630]

Lovenberg TW, Liaw CW, Grigoriadis DE, Clevenger W, Chalmers DT, De Souza EB, et al. Cloning and characterization of a functionally distinct corticotropin-releasing factor receptor subtype from rat brain. Proc Natl Acad Sci U S A 1995;92:836-840. [PubMed: 7846062]

Lu L, Liu Z, Huang M, Zhang Z. Dopamine-dependent responses to cocaine depend on corticotropinreleasing factor receptor subtypes. J Neurochem 2003;84:1378-1386. [PubMed: 12614338]

Makino S, Shibasaki T, Yamauchi N, Nishioka T, Mimoto T, Wakabayashi I, et al. Psychological stress increased corticotropin-releasing hormone mRNA and content in the central nucleus of the amygdala but not in the hypothalamic paraventricular nucleus in the rat. Brain Res 1999;850:136-143. [PubMed: 10629757]

Mantsch JR, Goeders NE. Ketoconazole does not block cocaine discrimination or the cocaine-induced reinstatement of cocaine-seeking behavior. Pharmacol Biochem Behav 1999;64:65-73. [PubMed: 10494999]

Mantsch JR, Katz ES. Elevation of glucocorticoids is necessary but not sufficient for the escalation of cocaine self-administration by chronic electric footshock stress in rats. Neuropsychopharmacology 2006;32:367-376. [PubMed: 16641943]

Mantsch JR, Saphier D, Goeders NE. Corticosterone facilitates the acquisition of cocaine selfadministration in rats: opposite effects of the type II glucocorticoid receptor agonist dexamethasone. J Pharmacol Exp Ther 1998;287:72-80. [PubMed: 9765324]

Mantsch JR, Yuferov V, Mathieu-Kia AM, Ho A, Kreek MJ. Neuroendocrine alterations in a high-dose, extended-access rat self-administration model of escalating cocaine use. Psychoneuroendocrinology 2003;28:836-862. [PubMed: 12892653] 
Marinelli M, Piazza PV. Interaction between glucocorticoid hormones, stress and psychostimulant drugs. Eur J Neurosci 2002;16:387-394. [PubMed: 12193179]

Marinelli M, Rouge-Pont F, Deroche V, Barrot M, De Jesus-Oliveira C, Le Moal M, Piazza PV. Glucocorticoids and behavioral effects of psychostimulants. I: locomotor response to cocaine depends on basal levels of glucocorticoids. J Pharmacol Exp Ther 1997;281:1392-1400. [PubMed: 9190875]

McElroy JF, Ward KA, Zeller KL, Jones KW, Gilligan PJ, He L, et al. The CRF(1) receptor antagonist DMP696 produces anxiolytic effects and inhibits the stress-induced hypothalamicpituitary-adrenal axis activation without sedation or ataxia in rats. Psychopharmacology 2002;165:86-92. [PubMed: 12474122]

Mello NK, Negus SS, Rice KC, Mendelson JH. Effects of the CRF(1) antagonist antalarmin on cocaine self-administration and discrimination in rhesus monkeys. Pharmacol Biochem Behav 2006;85:744751. [PubMed: 17182090]

Menzaghi F, Rassnick S, Heinrichs S, Baldwin H, Pich EM, Weiss F, Koob GF. The role of corticotropinreleasing factor in the anxiogenic effects of ethanol withdrawal. Ann N Y Acad Sci 1994;739:176184. [PubMed: 7832471]

Merlo-Pich E, Lorang M, Yeganeh M, Rodriguez de Fonseca F, Raber J, Koob GF, Weiss F. Increase of extracellular corticotropin-releasing factor-like immunoreactivity levels in the amygdala of awake rats during restraint stress and ethanol withdrawal as measured by microdialysis. J Neurosci 1995;15:5439-5447. [PubMed: 7643193]

Moffett MC, Goeders NE. CP-154,526, a CRF type-1 receptor antagonist, attenuates the cue-and methamphetamine-induced reinstatement of extinguished methamphetamine-seeking behavior in rats. Psychopharmacology 2007;190:171-180. [PubMed: 17119930]

Pecina S, Schulkin J, Berridge KC. Nucleus accumbens corticotropin-releasing factor increases cuetriggered motivation for sucrose reward: paradoxical positive incentive effects in stress? BMC Biol 2006;4:8. [PubMed: 16613600]

Piazza PV, Deroche-Gamonent V, Rouge-Pont F, Le Moal M. Vertical shifts in self-administration doseresponse functions predict a drug-vulnerable phenotype predisposed to addiction. J Neurosci 2000;20:4226-4232. [PubMed: 10818158]

Przegalinski E, Filip M, Frankowska M, Zaniewska M, Papla I. Effects of CP 154,526, a CRF 1 receptor antagonist, on behavioral responses to cocaine in rats. Neuropeptides 2005;39:525-533. [PubMed: 16139885]

Rassnick S, Heinrichs SC, Britton KT, Koob GF. Microinjection of a corticotropin-releasing factor antagonist into the central nucleus of the amygdala reverses anxiogenic-like effects of ethanol withdrawal. Brain Res 1993;605:25-32. [PubMed: 8467387]

Richter RM, Weiss F. In vivo CRF release in rat amygdala is increased during cocaine withdrawal in self-administering rats. Synapse 1999;32:254-261. [PubMed: 10332801]

Rodriguez de Fonseca F, Carrera MR, Navarro M, Koob GF, Weiss F. Activation of corticotropinreleasing factor in the limbic system during cannabinoid withdrawal. Science 1997;276:2050-2054. [PubMed: 9197270]

Rosner, B. Fundamentals of biostatics. Duxbury; Boston, MA: 1995.

Sabino V, Cottone P, Koob GF, Steardo L, Lee MJ, Rice KC, Zorrilla EP. Dissociation between opioid and $\mathrm{CRF}_{1}$ antagonist sensitive drinking in Sardinian alcohol-preferring rats. Psychopharmacology 2006;189:175-186. [PubMed: 17047935]

Shepard JD, Schulkin J, Myers DA. Chronically elevated corticosterone in the amygdala increases corticotropin releasing factor mRNA in the dorsolateral bed nucleus of stria terminalis following duress. Behav Brain Res 2006;174:193-196. [PubMed: 16934343]

Sinha R, Fuse T, Aubin LR, O'Malley SS. Psychological stress, drug-related cues and cocaine craving. Psychopharmacology 2000;152:140-148. [PubMed: 11057517]

Sheskin, DJ. Handbook of parametric and nonparametric statistical procedures. Chapman and Hall; Boca Raton: 2004. p. 678-679.

Strickley RG. Solubilizing excipients in oral and injectable formulations. Pharm Res 2004;21:201-230. [PubMed: 15032302] 
Vale W, Spiess J, Rivier C, Rivier J. Characterization of a 41-residue ovine hypothalamic peptide that stimulates secretion of corticotropin and beta-endorphin. Science 1981;213:1394-1397. [PubMed: 6267699]

Webster EL, Lewis DB, Torpy DJ, Zachman EK, Rice KC, Chrousos GP. In vivo and in vitro characterization of antalarmin, a non-peptide corticotropin-releasing hormone $(\mathrm{CRH})$ receptor antagonist: suppression of pituitary ACTH release and peripheral inflammation. Endocrinology 1996;137:5747-5750. [PubMed: 8940412]

Wee S, Specio SE, Koob GF. Effects of dose and session duration on cocaine self-administration in rats. J Pharmacol Exp Ther 2007;320:1134-1143. [PubMed: 17202405]

Weiss F, Ciccocioppo R, Parsons LH, Katner S, Liu X, Zorrilla EP, Valdez GR, Ben-Shahar O, Angeletti $\mathrm{S}$, Richter RR. Compulsive drug-seeking behavior and relapse. Neuroadaptation, stress, and conditioning factors. Ann N Y Acad Sci 2001;937:1-26. [PubMed: 11458532]

Winer, BJ. Statistical principles in experimental design. McGraw-Hill; New York: 1962.

Zhao YH, Abraham MH, Ibrahim A, Fish PV, Cole S, Lewis ML, de Groot MJ, Reynolds DP. Predicting penetration across the blood-brain barrier from simple descriptors and fragmentation schemes. $\mathrm{J}$ Chem Inf Model 2007;47:170-175. [PubMed: 17238262]

Zorrilla EP, Koob GF. The therapeutic potential of $\mathrm{CRF}_{1}$ antagonists for anxiety. Expert Opin Investig Drugs 2004;13:799-828.

Zorrilla EP, Valdez GR, Weiss F. Changes in levels of regional CRF-like-immunoreactivity and plasma corticosterone during protracted drug withdrawal in dependent rats. Psychopharmacology 2001;158:374-381. [PubMed: 11797058]

Zorrilla EP, Valdez GR, Nozulak J, Koob GF, Markou A. Effects of antalarmin, a CRF type 1 receptor antagonist, on anxiety-like behavior and motor activation in the rat. Brain Res 2002;952:188-199. [PubMed: 12376179] 
$\sim N$<smiles>Cc1nc(C)c2c(C)c(C)[nH]c2n1</smiles><smiles>Cc1cc(C)c(C)c(C)c1</smiles>

Antalarmin

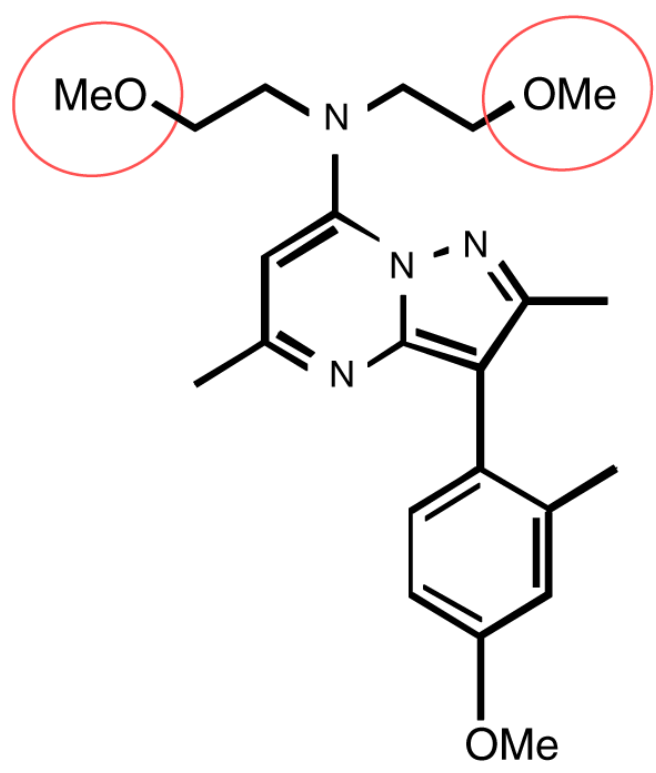

MPZP

Fig. 1.

Chemical structures of antalarmin and MPZP 


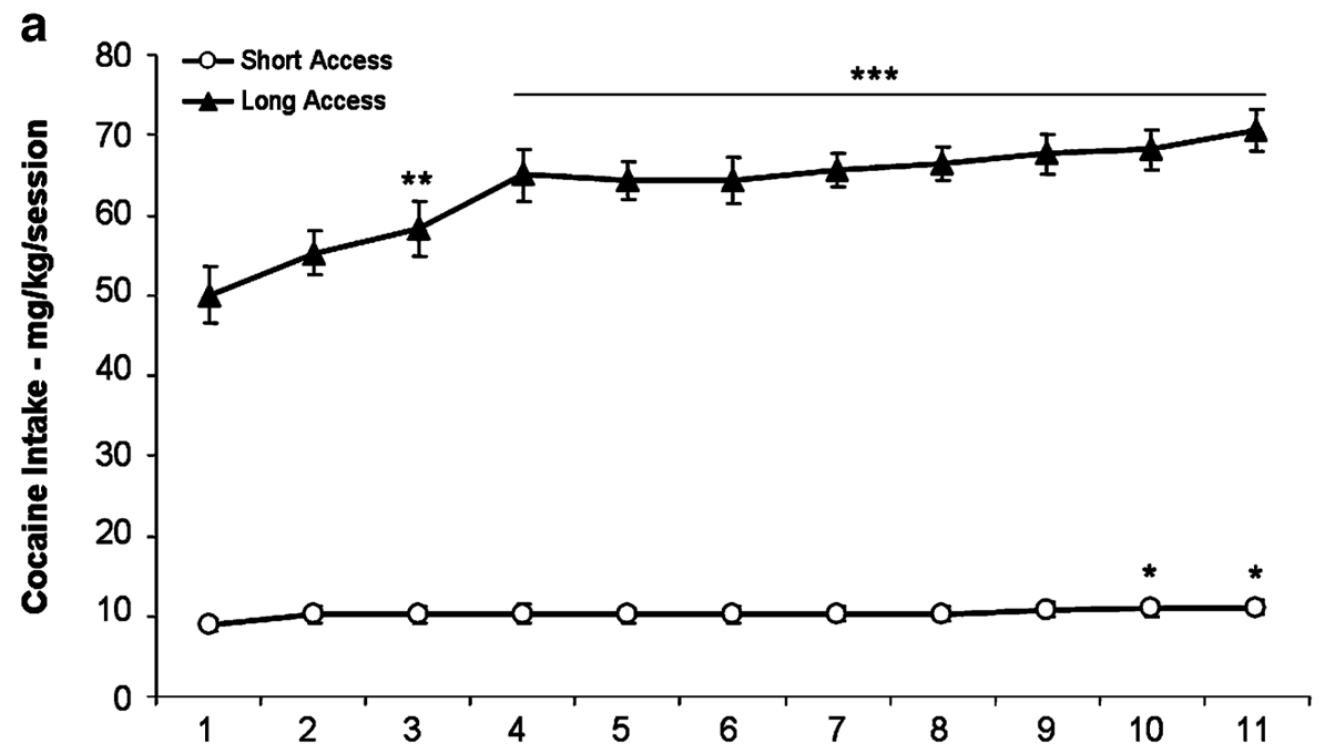

Day of Escalation Phase

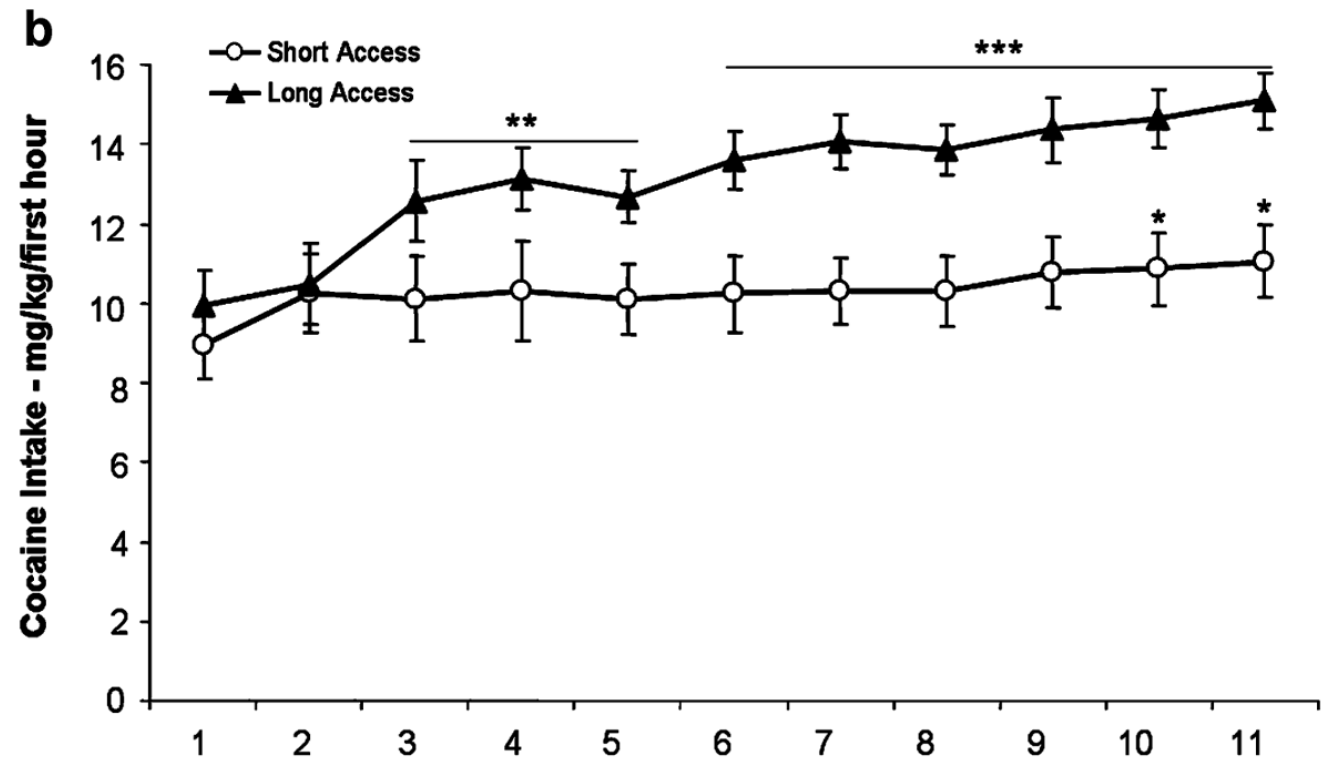

Day of Escalation Phase

Fig. 2.

Self-administration of cocaine by rats under a fixed-ratio schedule during the escalation period. Data from entire sessions (a) and from the first hour of sessions (b). The data represent mean (+SEM) cocaine intake adjusted for body weight (milligram per kilogram). Open symbols are the data for rats in 1-h sessions (ShA, $n=16$ ). Filled symbols are the data for rats in 6-h sessions (LgA, $n=16) .{ }^{*} p<0.05, * * p<0.01,{ }^{* * *} p<0.001$ compared with session 1 


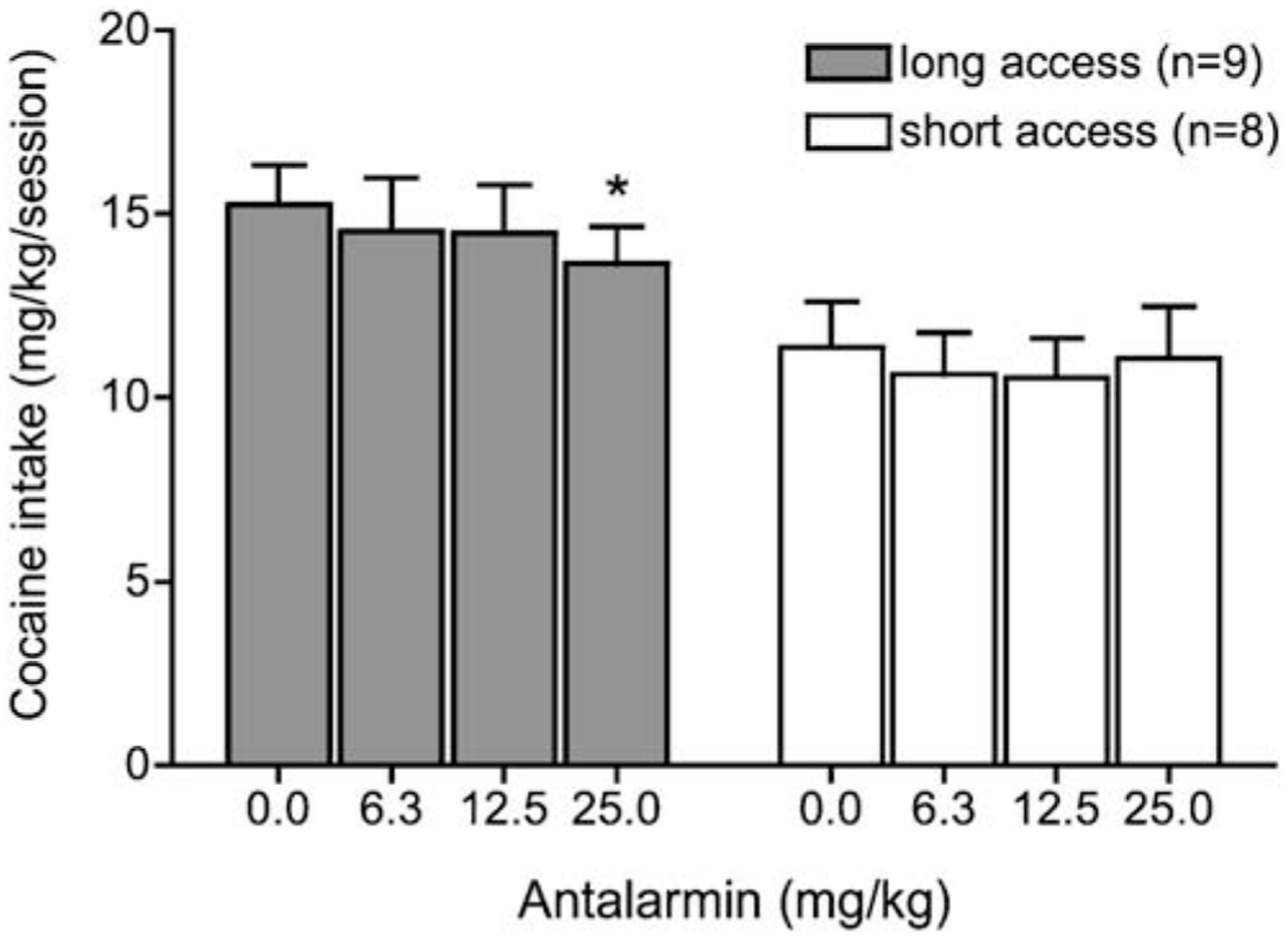

Fig. 3.

Antalarmin effects on cocaine intake in ShA and $\operatorname{LgA}$ rats under a fixed-ratio schedule. Antalarmin was intraperitoneally injected 80 min before a test session. Test sessions lasted 1 $\mathrm{h}$ and were separated by one or two treatment-free escalation sessions. Data are expressed as mean $(+\mathrm{SEM})$ cocaine intake (milligram per kilogram). ${ }^{*} p<0.05$ compared with the vehicle 


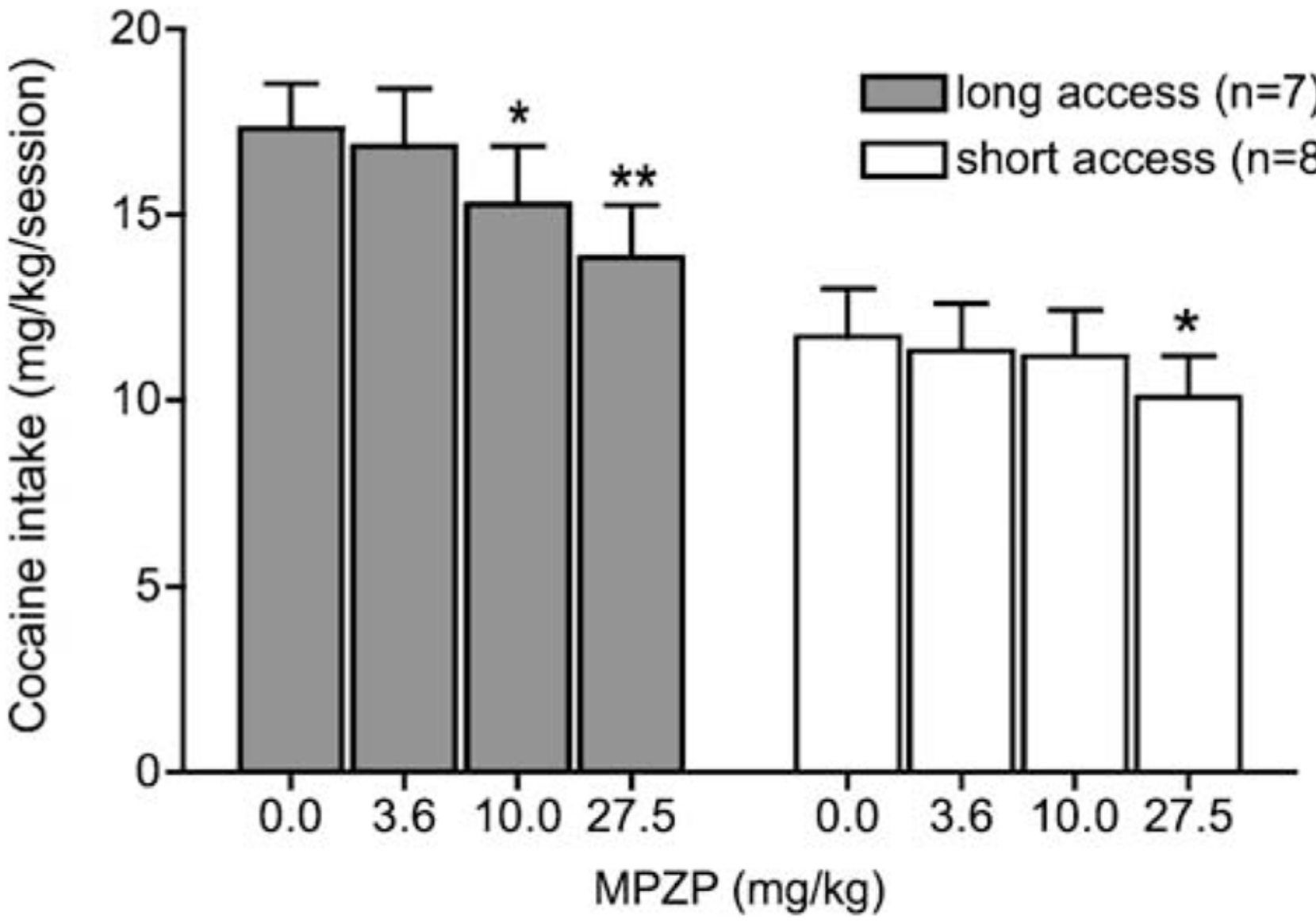

Fig. 4.

MPZP effects on cocaine intake in ShA and LgA rats under a fixed-ratio schedule. MPZP was subcutaneously injected $45 \mathrm{~min}$ before a test session. Test sessions lasted $1 \mathrm{~h}$ and were separated by one or two treatment-free escalation sessions. Data are expressed as mean (+SEM) cocaine intake (milligram per kilogram). ${ }^{*} p<0.05, * * p<0.01$ compared with the vehicle 
Table 1

Selected pharmacological and physiochemical properties of antalarmin and MPZP

\begin{tabular}{lll}
\hline & Antalarmin & MPZP \\
\hline CAS registry number & $157284-96-3$ & $202579-79-8$ \\
Affinity at rat $\mathrm{CRF}_{1}$ receptor $\left(K_{\mathrm{i}}, \mathrm{nM}\right)$ & $1^{a}$ & $5-10^{b}$ \\
$\operatorname{cLog} P$ & $7.09+1.31$ & $2.95+1.13$ \\
cLog $D, \mathrm{pH} 7$ & 6.41 & 2.93 \\
Polar surface area $\left(\AA^{2}\right)$ & 29 & 61.1 \\
pKa & $7.48+0.30$ & $5.32+0.30$ \\
Molar volume $\left(\mathrm{cm}^{3} / \mathrm{mol}\right)$ & $357.2+7.0$ & $346.2+7.0$ \\
\hline
\end{tabular}

Physiochemical properties were calculated using Advanced Chemistry Development (ACD/Labs) Software v8.14 for Solaris (ACD/Labs).

CAS Chemical Abstracts Service

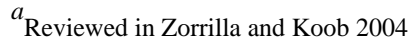

${ }^{b}$ Estimated from displacement of [ $\left.{ }^{125} \mathrm{I}\right]-\mathrm{Tyr}^{0}$-sauvaine from rat cerebellar homogenates in four independent replications 